\title{
THE IMPORTANCE OF NATURAL ELEMENTS FOR THE DEVELOPMENT OF TOURISM IN NEGORSKA SPA - GEVGELIJA IN MACEDONIA
}

DOI: http://dx.doi.org/10.18509/GBP.2015.41

UDC: $338.4864625 .838(497.715)$

\author{
PhD Koteski Cane ${ }^{1}$ \\ Prof. Dr. Nikola V. Dimitrov ${ }^{2}$ \\ Prof. Dr. Zlatko Jakovlev ${ }^{3}$ \\ ${ }^{1}$ Fakulty Tourism and Business Logistics - University „Goce Delchev“- Stip, Macedonia
}

\begin{abstract}
In this paper the natural elements are presented: geographic - orographic position, relief, climate, hydrography and geology of the area of non-forest spa. Special emphasis will be put on a weather climate and hydrothermal features, such as: air temperature, humidity, precipitation, insolation, spa features water therapy treatment, drinking and more. Features that have a direct impact on the development of spa tourism in Negorska spa Gevgelija.
\end{abstract}

Keywords: natural elements, weather, climate, hydrothermal, spa tourism.

\section{INTRODUCTION}

Gevgelija municipality occupies SE part of Macedonia, borders with a country of the European Union (Greece). It covers an area of 48.5 hectares or $485 \mathrm{~km} 2$. Negorci Negorski and spas are on the SE slopes of Mount Kozuf, $5 \mathrm{~km}$ north - west of the city of Gevgelija, and at an altitude of only 59 meters. Also, it is the lowest spa in Macedonia. This spa is considered to be used firstly by Shukri - Pasha.

\section{TRANSPORT CONNECTION}

Here goes the highway E75 (European Corridor 10) which connects Central Europe with Greece and Asia Minor. The spa by air is connected to the world through airports in Skopje Petrovac $(169 \mathrm{~km})$, Ohrid $(262 \mathrm{~km})$ and Thessaloniki $(99 \mathrm{~km})$. Vardar river, which is not navigable. 


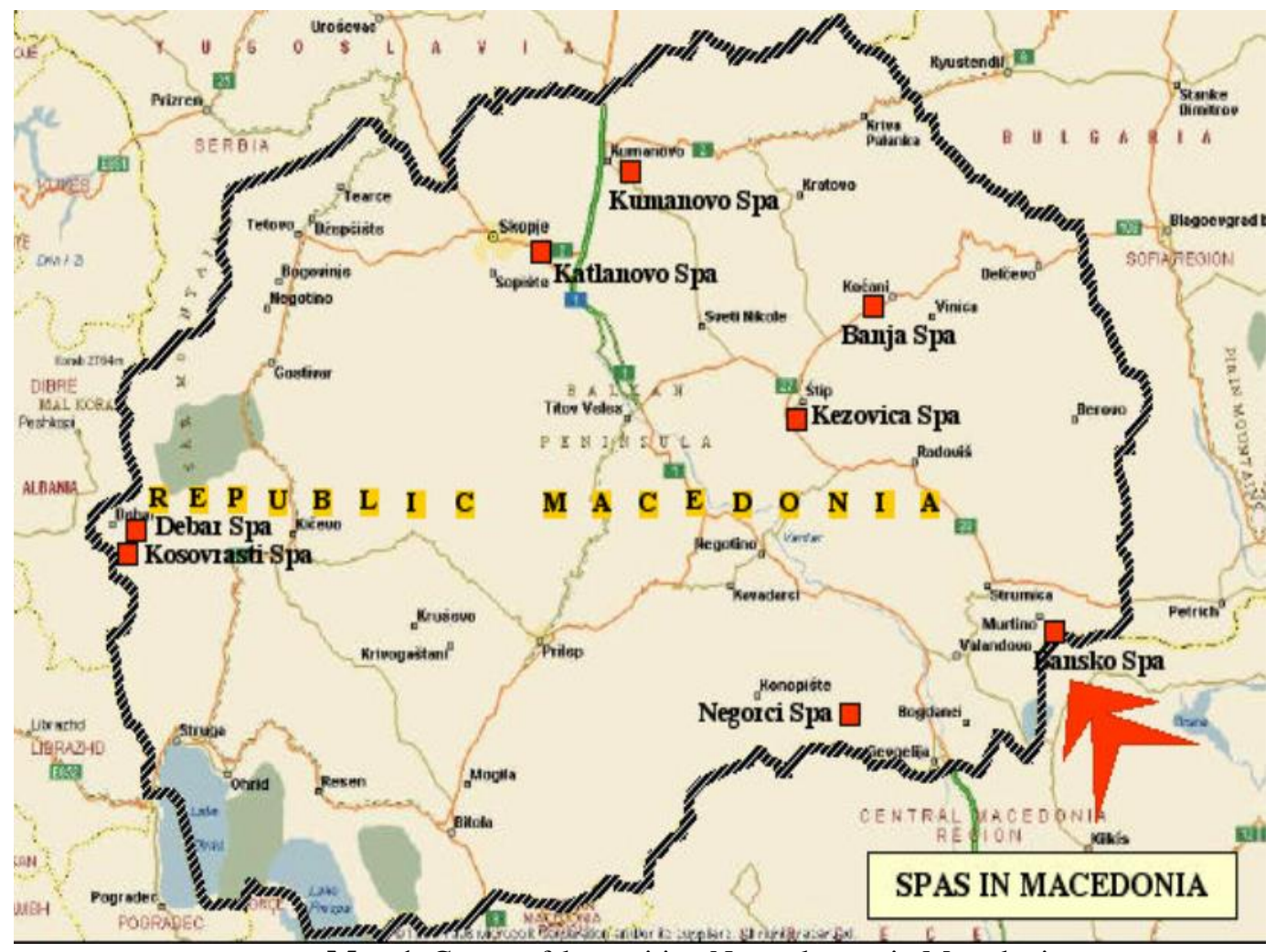

Map 1. Geopgrafska position Negorska spa in Macedonia

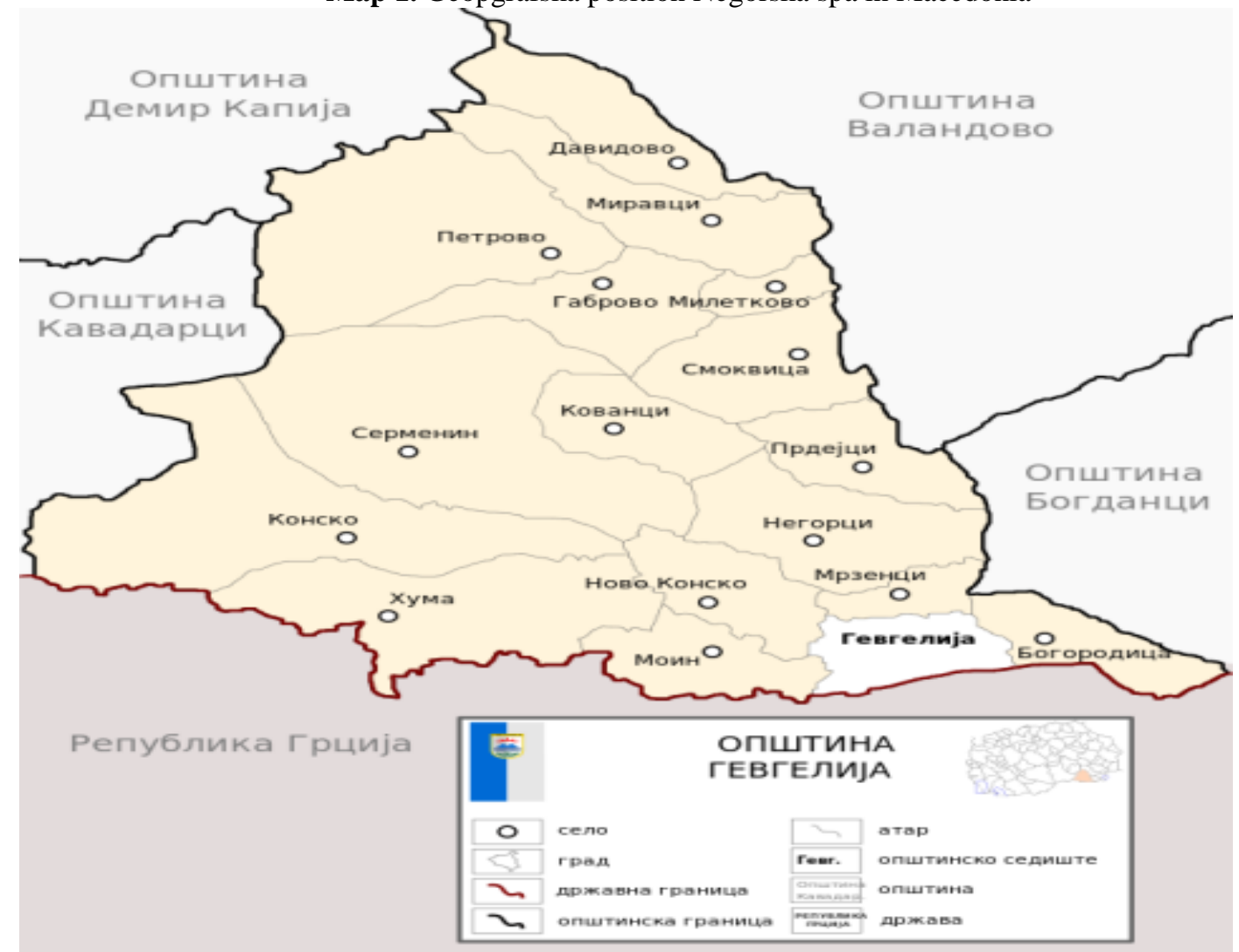

Map 2. Geographical location of the Municipality of Gevgelija in Macedonia 


\section{RELIEF FEATURES}

Relief rather affects the climate of the flora and fauna as well as the distribution of the population and the determination of its lifestyle. According to geological and pedological composition and morphological characteristics of the area the spa separates into different parts.

Most important for the spa Mount Kozuv where dyskinesia sides down to the spa and is an important factor for the development of tourism, especially for picnic recreational activities. Beautiful landscapes and forest vegetation provide beautiful walks.

\section{CLIMATE CHARACTERISTICS OF THE SPA AREA}

The spa is influenced by the Mediterranean, it is located only $80 \mathrm{~km}$ from the coast of the Gulf. On the north it is surrounded by mountains and the continental influence from the north of Macedonia is poorly felt.

\section{AIR TEMPERATURE}

In the period 1961-1990, Negorska spa has the highest air temperature of all spas in Macedonia 14. $0^{\circ} \mathrm{C}$, while in the period 1991-2013 year highest average annual air temperature was recorded in 2013 of $16.3^{\circ} \mathrm{C}$. The highest temperatures occur from June to September, especially in July and August. This temperature allows excellent conditions for the hat season. In winter the temperature does not fall below zero and it provides excellent living conditions through winter, in the spa, which is a huge advantage over other spas in Macedonia. Between 1961-1990 and 1991- 2013 year notice an increase in air temperature in the area of non-forest spa of $14^{\circ} \mathrm{C}$ to $16.3^{\circ} \mathrm{C}$.

Table 1. Average annual air temperature in ${ }^{\circ} \mathrm{C}$ in the area of non-forest spa in Gevgelija - R. Macedonia in the period 1961-1990 and 1991-2013godina.

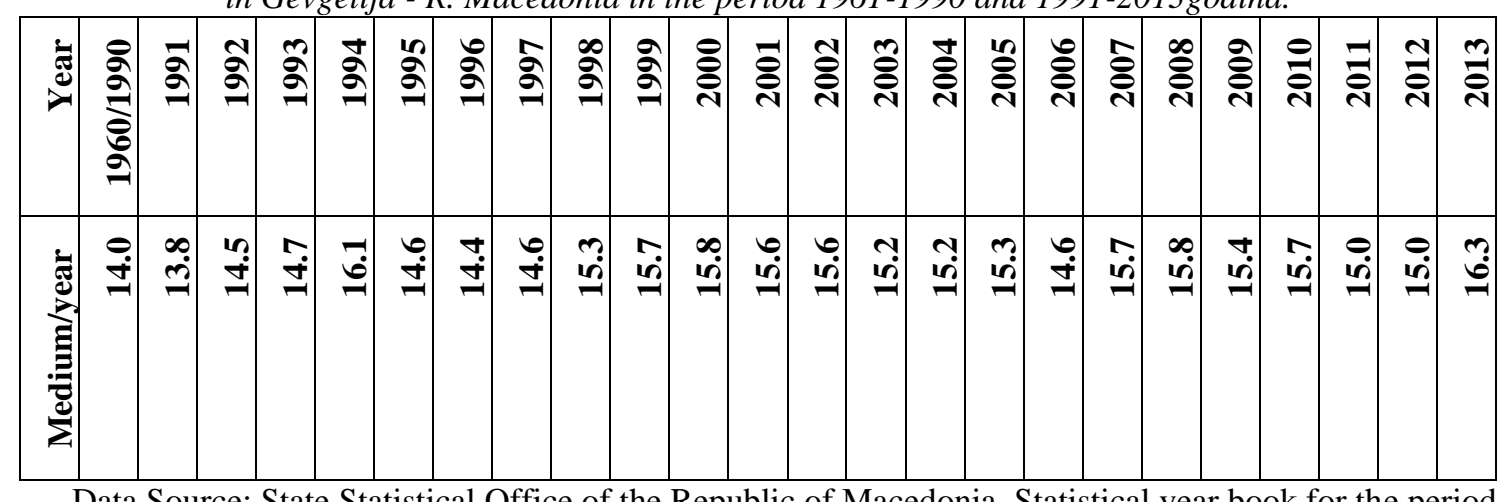

Data Source: State Statistical Office of the Republic of Macedonia, Statistical year book for the period 1962-2014 year. 


\section{PRECIPITATION}

According precipitation Negorska spa has a Mediterranean regime.

Table 2. Annual amounts of rainfall ( $\mathrm{mm})$ in the area of non-forest spa - Gevgelija in Macedonia.

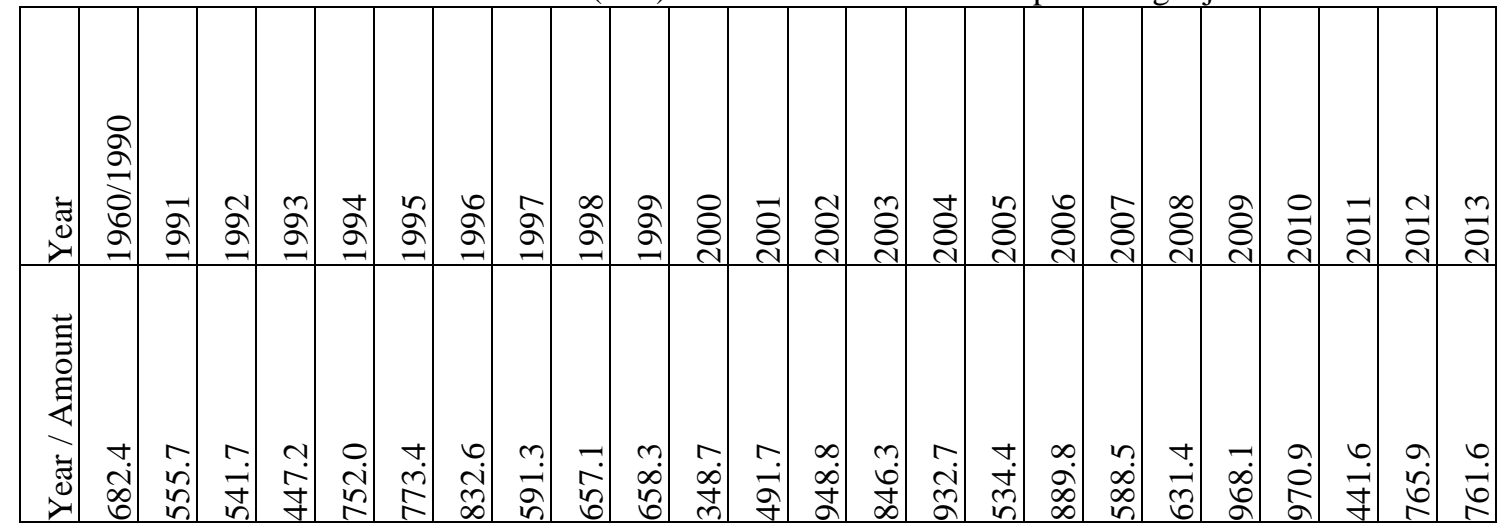

Data Source: State Statistical Office of the Republic of Macedonia, Statistical yearbook for the period 1962-2014 year.

In the period 1961-1990, the maximum in the months of November and December $93.1 \mathrm{~mm} 74.1 \mathrm{~mm}$, while the period from 1991 to 2013 year the maximum was recorded in 2010 in the months of February to October $168.0 \mathrm{~mm} 334.8 \mathrm{~mm}$. According to the table we see that precipitation for the period 1961-1990 is higher by $18.4 \mathrm{~mm}$ in the period 1991 to 2013 year, where the average annual precipitation is $664.0 \mathrm{~mm}$ mean precipitation in the last 23 years of continuous decline in the area of non-forest spa. Most of the precipitation during the year in the form of rain.

\section{SOLAR INSOLATION}

The area of non-forest spa has the lowest number of cloudy days of all spas in Macedonia. On average there are 69.4 days and a tourist importance value.

Table 3. A year in the amount of osonchuvanje (hours) in the area of non-forest spa - Gevgelija R. Macedonia in the period 1961-2013 year.

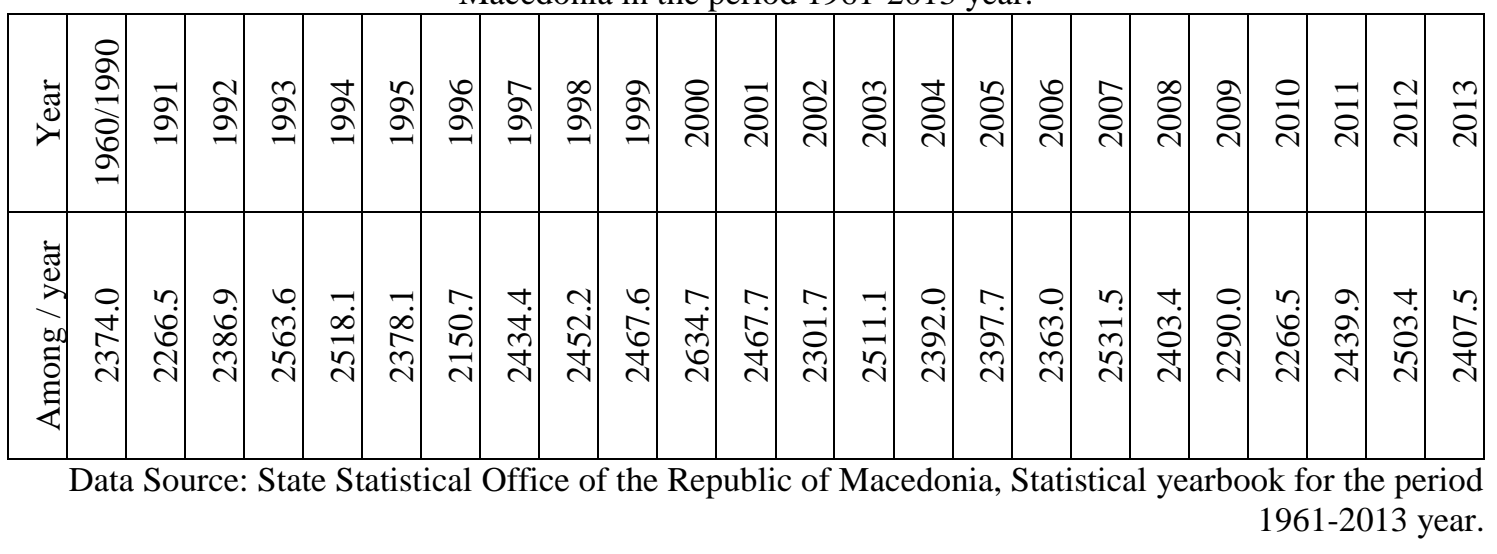

Total insolation between 1961-1990 totaled 2374.0 hours is one of the most important tourist values which Negorska spa has in relation to all other spas in Macedonia. The insolation is most permanent during the summer months and is very important for tourist arrivals to the spas. In the period 1991-2013, the greatest insolation was in 2000 where insolation reached 2634.7 hours. In the period 1991-2013, the average annual insolation was 2414.3 hours an increase of insolation for 40.3 hours in the period 1961-1990. 


\section{RELATIVE HUMIDITY}

Relative humidity is also a very important climate elementfor the curing opportunities of the spa.

Table 4. Annual relative humidity in the area of non-forest spa - Gevgelija - R. Macedonia in the period 1951-1975 and the 1991-2013 year.

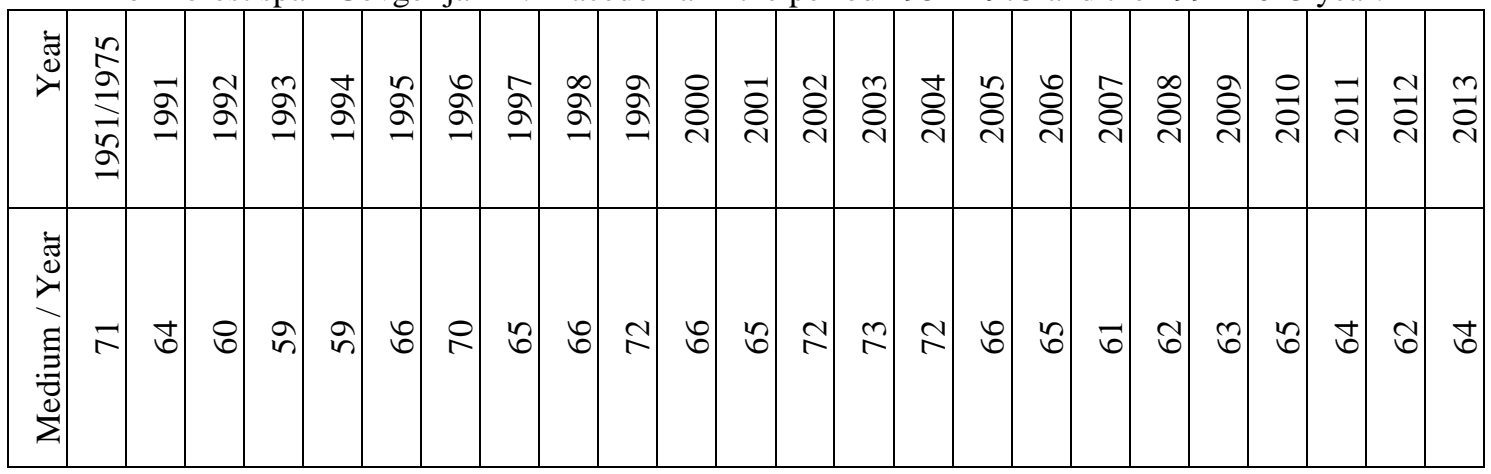

Data Source: State Statistical Office of the Republic of Macedonia, Statistical yearbook for the period 1952-1976 and the 1992-2014 year.

Between 1951- 1975 years the average annual humidity amounted to $71 \%$, while in the period from 1991 to 2013, the highest relative humidity was in $200273 \%$. In the past 23 years from 1991-2013 the average annual relative humidity amounted to $65.3 \%$. In the period 1951-1975, the relative humidity was reduced to $5.7 \%$.

\section{WINDS IN (\%o)}

Table 5. Average annual frequency of wind (\%) in the area of non-forest spa - Gevgelija - R. Macedonia.

\begin{tabular}{|l|c|c|c|c|c|c|c|c|c|}
\hline Place & N & NE & E & SE & S & SW & W & NW & C \\
\hline Gevgelija & 224 & 23 & 70 & 101 & 73 & 29 & 27 & 136 & 317 \\
\hline
\end{tabular}

Winds have low speed and perform ventilation and act refreshingly. In the space of Vardarec Negorska bath appears NW wind at an annual frequency of $136 \%$, the wind moves from the mountain Kozuv along the river Sermenska. This wind occurs in the summer months of July with frequency of $238 \%$ and August of $220 \%$.

\section{FEATURES OF THE WATER AND CURING CAPABILITIES}

Water springs have volcanic origin. There are three sources, that "hot spa", with temperature of $40^{\circ} \mathrm{C}$, and "cold spa" with water temperature of $36^{\circ} \mathrm{C}$, New measurements $40^{\circ} \mathrm{C}$. In its chemical and physical properties the water is homo thermal, slightly mineralized and slightly radioactive. The main chemical composition of the water comprises of sodium sulfate. The water is used for the treatment of: a neurological disorders, gynecological disorders, respiratory disease, chronic bronchitis - laryngitis and tracheitis, chronic gastritis, ulcers and stomach cancer, inflammatory bile, inflammatory bowel disease, disorders of the locomotors system, condition after rheumatic fever, Behterova disease - initial stage, degenerative rheumatism (arthritis, spondylosis), extraarticular rheumatism, consequences of trauma and war wounding, uric diathesis inperiodically stronger deterioration, cardio vascular diseases, all forms of coronary disease, chronic inflationary motor rheumatism, chronic evolutionary polyarthritis. 


\section{CONCLUSION}

- Negorska spa has a favorable geographical position;

- The spa has a favorable road, rail and air connection;

- The spa has a favorable landscape features;

- Average annual air temperature in the period 1961-90 and 1991 / 2013year increased from $14^{\circ} \mathrm{C}$ to $16.3^{\circ} \mathrm{C}$;

- Precipitation mostly represented by rain, precipitation in the period 1961-90 is higher by $18.4 \mathrm{~mm}$ compared to the period from 1991 / 2013year;

- Relative humidity in the period 1991 / 2013year decreased in the period 1951 / 75 year of $5.7 \%$;

- The most common winds in the area of non-forest spa Vardarec, NW and local winds.

- Water from Negorska spa has tremendous healing capabilities.

\section{REFERENCE}

[1] Angel Lazarevski. The climate in Macedonia, education, Kumanovo, Macedonia, 1993, pp 18-96;

[2] Angel Lazarevski. Impact of the Mediterranean climate in Macedonia, Macedonian treasury, Kumanovo, Macedonia, 1997, pp 39 -171;

[3] Alexander Stojmilov. Negorska bathroom Geographical considerations, book 15 -16 Volume, Skopje, Macedonia, 1978, pp 45-55;

[4] Cane Koteski \& Nikola Dimitrov\& Zlatko Jakovlev. Opportunities for development of spa tourism in R.Macedonia. LAP Lambert Academic Publishing,

Deutschland/Germany, 2014, pp 158-185. 